\title{
PENGARUH BEBAN KERJA DAN KOMUNIKASI TERHADAP PRODUKTIVITAS KERJA KARYAWAN PADA PT WONEEL MIDAS LEATHERS DI TANGERANG
}

\author{
Siti Nursiah \\ Dosen Fakultas Ekonomi dan Bisnis, Universitas Muhammadiyah Tangerang \\ Fat Sarifah \\ Mahasiswa Fakultas Ekonomi dan Bisnis, Universitas Muhammadiyah Tangerang
}

Penelitian ini bertujuan untuk mengetahui Pengaruh beban kerja dan komunikasi terhadap produktivitas kerja karyawan pada PT. Woneel Midas Leathers di Tangerang. Metode penelitian ini menggunakan penelitian kuantitatif. Jumlah populasi yang penelitian ini sebanyak 200 dengan jumlah sampel sebanyak 67 orang dengan taraf kesalahan 10\%. Data yang dikumpulkan menggunakan metode angket dengan skala Likert dan wawancara. Metode analisis penelitian ini menggunakan (1) Uji Validitas, (2) Uji reabilitas, (3) Analisis regresi sederhana, (4) Analisis regresi berganda, (5) Analisis korelasi sederhana, (6) Analisisis korelasi berganda, (7) Analisisi koefisien determinasi, (8) Uji t, (9) Uji f.

Hasil penelitian ini menunjukkan bahwa: (1) Beban Kerja berpengaruh terhadap Produktivitas kerja karyawan dapat dilihat dari hasil perhitungan analisis regresi sederhana yaitu $\mathrm{Y}=22,550+0,441 \mathrm{X}_{1}$. (2) Komunikassi berpengaruh terhadap Produktivitas Kerja Karyawan dari hasil perhitungan analisis regresi sederhana yaitu $\mathrm{Y}=22,240+0,439 \mathrm{X}_{2}$. (3) beban kerja dan komunikasi berpengaruh terhadap produktivitas kerja dapat dilihat dari hasil perhitungan analisis regresi ganda yaitu $\mathrm{Y}=16,739+0.268 \mathrm{X}_{1}+0.324 \mathrm{X}_{2}$. (4) $\mathrm{R}$ Square Beban Kerja dan Komuikasi dengan Produktivitas Kerja adalah sebesar 0.503.

Kata Kunci: Beban Kerja, Komunikasi, Produktivitas Kerja Karyawan

\section{PENDAHULUAN}

\section{A. Latar Belakang Masalah}

Setiap perusahaan pasti menginginkan karyawannya memiliki kemampuan produktivitas yang tinggi, tujuannya adalah untuk mendapatkan profit yang harus didukung oleh kemampuan optimal karyawan tersebut. Dimana perusahaan harus memiliki orang-orang yang produktif untuk mengelola perusahaan dengan baik. Untuk memiliki orang-orang yang produktif perusahaan melakukan pelatihan-pelatihan khusus untuk para karyawannya.

Dalam menjalankan tugas dan tanggung jawabnya, manajemen sumber daya manusia sering dihadapkan pada masalah-masalah yang bersifat dinamik. Namun untuk mendapatkan karyawan yang sesuai dengan harapan perusahaan tidak dapat dilakukan dengan waktu yang singkat karena selain faktor pendidikan, umur, dan pengalaman masih ada hal lain yang perlu diperhatikan. Tinggi rendahnya kualitas karyawan sangat berpengaruh dalam pengembangan dan peningkatan produktivitas dalam berbagai unit. Hal tersebut dikarenakan karyawan memegang peranaan penting dalam usaha untuk mencapai tujuan perusahaan.

Perusahaan harus mempunyai kemampuan untuk menggunakan sumber-sumber secara optimal dan menciptakan sistem kerja yang maksimal akan tinggi rendahnya produktivitas karyawan. Peranan manajemen sangat strategis untuk meningkatkan produktivitas, yaitu dengan mengkombinasikan dan mendayakan semua sarana dan prasarana, menerapkan fungsi-fungsi manajemen menciptakan sistem kerja dan pembagian kerja, menempatkan orang yang tepat, serta menciptakan kodisi dan lingkungan kerja aman dan nyaman. Sehingga menciptakan pekerjaan yang optimal dan produktif (Hadi Kusuma, 2014:4). 
Menurut Meshkati dalam Tarwaka (2015) beban kerja dapat didefinisikan sebagai suatu perbedaan anatara kapasitas atau kemampuan kerja dengan tuntutan pekerjaan yang harus dihadapi. Perusahaan harus bisa memperhatikan beban kerja karyawannya agar bisa sesuai dengan kapasitas kerja yang dimiliki oleh para karyawannya. Sehingga produktivitas karyawannya bisa tercapai. Beban kerja tersebut dapat berupa beban fisik maupun beban mental.

Beban kerja timbul karena adanya tugas-tugas yang diberikan kepada karyawan yang mempunyai tanggung jawab masing-masing baik itu kerja sebagai satu kesatuan atau grup maupun secara individu. Dengan meningkatkan beban kerja oleh perusahaan maka karyawan dituntut lebih produktif yaitu dengan jumlah pekerjaan yang harus dikerjakan oleh setiap karyawan secara maksimal dan optimal (Hadi Kusuma, 2014: 4).

PT. WONEEL MIDAS LEATHERS merupakan perusahaan yang bergerak dibidang industri sarung tangan kulit yang memiliki karyawan lebih dari 200 orang. Pada bagian produksi terdiri dari beberapa bagian, yaitu: cutting, order, tempel, line sewing, sewing computer, QC/QA, dan packing. Setiap proses kerja tersebut memiliki beban kerja yang berbeda-beda, adapun beban kerja yang tinggi dirasakan oleh karyawan pada bagian sewing. Beban kerja yang tinggi tersebut dikarenakan pada bagian sewing karyawannya bekerja tidak hanya satu proses saja, tetapi mereka harus melakukan beberapa proses kerja dalam kapasitas waktu yang telah ditentukan. Selain itu faktor-faktor yang mempengaruhi beban kerja karyawan sewing yang melebihi kapasitas kerja adalah kondisi lingkungan, perilaku pimpinan, target yang semakin bertambah dengan bobot kerja yang melebihi kapasitas, sehingga mengakibatkan produktivitas kerja karyawan menurun.

\section{Tabel 1.1 Hasil Kerja Karyawan}

\begin{tabular}{|c|l|c|c|c|}
\hline Sewing & jenis Jahitan & $\begin{array}{c}\text { Target/h } \\
\text { ari (pcs) }\end{array}$ & $\begin{array}{c}\text { Target } \\
\text { /jam }\end{array}$ & $\begin{array}{c}\text { Total/ } \\
\text { hari }\end{array}$ \\
\hline Line 1 & Fr ground glove & 840 & 108 & 864 \\
\hline Line 2 & Luv WC & 770 & 78 & 624 \\
\hline Line 3 & Mizuno Comp & 840 & 136 & 1.088 \\
\hline Line 4 & B-303 & 700 & 85 & 680 \\
\hline
\end{tabular}

Sumber: PT. Woneel Midas Leathers

Oleh sebab itu beban kerja harus sesuai dengan kemampuan yang dimiliki seorang sumber daya manusia tersebut, atau masih dalam batas kapasitas kerja yang dimiliki oleh sumber daya manusia tersebut dalam hal iini yaitu karyawan PT. WONEEL MIDAS LEATHERS.

Walaupun perusahaan menginginkan setiap karyawan harus fleksibel akan tetapi hal ini dapat mengakibatkan para karyawan menjadi cepat merasa kelelahan baik fisik maupun mental. Karena tubuh manusia mempunyai batas tertentu dalam hal beraktivitas. Kalau melebihi batas tersebut dapat menimbulkan stres dan ketidaknyamanan dalam bekerja dan tidak dapat berkomunikasi dengan baik atar bagian maupun atasan, dan komunikasipun tidak berjalan sebagaimana mestinya.

Komunikasi memiliki peranan penting dalam kehidupan manusia. Dengan berbicara, manusia akan memperoleh suatu informasi yang berguna baginya dan sosial. Karena komunikasi menurut Prabawa (2013:19 dalam Lalujan, dkk: 2016: 133) mengatakan bahwa komunikasi organisasi merupakan arus informasi, pertukaran informasi dan pemindahan arti dalam suatu organisasi. Komunikasi dalam perusahaan merupakan penentu keberhasilan dalam pencapaian tujuan, dengan komunikasi akan terjadi hubungan timbal balik dari tiap-tiap orang dalam perusahaan baik berupa perintah, saran, pendapat maupun kritik

Dalam perusahaan, sumber daya manusia yang produktif dapat tercapai apabila karyawan-karyawan memiliki kemampuan yang luas, disiplin, dan memahami pekerjaannya dan mengetahui apa-apa yang dilaksanakan serta bertanggung jawab atas pekerjaannya itu. Karyawan harus memahami arti penting dari komunikasi yang efisien dan tepat guna. Tanpa adanya komunikasi yang baik, maka akan sulit mengadakan koordinasi, karena itu perwujudan komunikasi ini memiliki peran yang sangat penting.

Disini komunikasi baik antara staf kepada manajer, dan antara kepala bagian kepada karyawan produksi harus berjalan dengan lancar agar tidak terjadi kesalahan dalam memberikan informasi. Karena komunikasi dalam bidang manufaktur sangat dibutuhkan untuk meminimalkan kejadian buruk yang terjadi. Komunikasi juga dapat diinformasikan kepada setiap bagian atau divisi tentang masalahmasalah yang terjadi nanti dan masalah tersebut dapat diselesaikan.

Berdasarkan uraian diatas penulis tertarik dengan judul "PENGARUH BEBAN KERJA DAN KOMUNIKASI TERHADAP PRODUKTIVITAS KERJA KARYAWAN PADA PT WONEEL MIDAS LEATHERS DI TANGERANG". Karena penulis ingin mengetahui 
pengaruh beban kerja dan komunikasi yang ada pada perusahaan tersebut.

\section{TINJAUAN PUSTAKA}

\section{A. Landasan Teori Manajemen}

Manajemen adalah suatu proses pengelolaan sumber daya untuk mewujudkan tujuan yang ingin dicapai (Karyoto, 2016: 2). Manajemen sebagai batasan usaha yang dilakukan dengan dan bersama individu atau kelompok untuk mencapai tujuan organisasi. Dalam penelitian tersebut dirumuskan bahwa tidaklah dimaksudkan hanya untuk organisasi saja, tetapi dapat diterapkan pada berbagai jenis organisasi tempat individu atau kelompok tersebut menggabungkan diri untuk mewujudkan tujuan bersama (Siswanto, 2016:2).

Manajemen adalah upaya untuk mencapai apa yang ingin dicapai oleh perusahaan dengan memanfaatkan organisasi perusahaan mereka. Para manajer tersebut menggunakan keahlian manajerial (managerial skill) yang mereka miliki untuk mengelola berbagai sumber daya organisasi sehingga tujuan perusahaan dapat dicapai (Solihin, 2016:3).

\section{B. Manajemen Sumber Daya Manusia}

MSDM adalah proses pengelolaan manusia, melalui perencanaan, rekruitmen, seleksi, pelatihan, pengembangan, pemberian kompensasi, karier, keselamatan dan kesehatan serta menjaga hubungan industrial sampai pemutusan hubungan kerja guna mencapai tujuan perusahaan dan peningkatan kesejahteraan stakeholder (Kasmar 2015:6).

Menurut Simamora dan Sutrisno (2015:5) Manajemen Sumber Daya Manusia merupakan pendayagunaan,pengembangan,penilaian, pemberian balas jasa, dan pengelolaan individu suatu organisasi maupun kelompok pekerja.

\section{Produktivitas Karyawan}

Produktivitas memiliki arti sebagai perbandingan antara hasil yang dicapai antara output dengan keseluruhan sumber daya yang digunakan input. Dengan kata lain produktivitas memiliki dua dimensi. Dimensi yang pertama adalah efektivitas yang mengarah kepada pencapaian untuk kerja yang maksimal yaitu pencapaian target yang berkaitan kualitas, kuantitas, dan waktu. Yang kedua yaitu, efisiensi yang berkaitan dengan upaya membandingkan input dengan realisasi penggunanya atau bagaimana pekerjaan tersebut dilaksanakan (Ashar, 2015).
Berbagai indikator produktivitas kerja karyawan yang dikemukakan oleh Sutrisno (2012: 104-105) diantaranya adalah kemampuan, meningkatkan hasil ang dicapai, semangat kerja, pengembangan diri dan mutu.

\section{Beban Kerja}

Beban kerja adalah suatu kondisi dari pekerjaan dengan uraian tugasnya yang harus diselesaikan pada batas waktu tertentu (Tarwaka, 2013).

Bahwa beban kerja merupakan sesuatu yang muncul dari interaksi antara tuntutan tugas-tugas, lingkungan kerja dimana digunakan sebagai tempat kerja, keterampilan, perilaku dan persepsi dari pekerja (Hart dan Staveland dalam Tarwaka, 2015).

Dalam penelitian ini indikator beban kerja yang digunakan mengadopsi dari indikator bebean kerja yang dikemukakan oleh Putra (2014: 22), yang meliputi antara lain: Target yang dicapai, Kondisi Pekerjaan dan Standar Pekerjaan.

\section{E. Komunikasi}

Secara etimologis komunikasi berasal dari Bahasa Latin, yaitu cum, kata depan yang memiliki arti dengan atau Bersama dengan, dan kata units, kata bilangan yang berarti satu. Selanjutnya, kata tersebut akan membentuk kata benda yaitu communio, dalam Bahasa inggris disebut dengan communion, artinya kebersamaan, persatuan, persekutuan, gabungan, pergaulan, atau hubungan. Karena untuk melakukan communion, diperlukan usaha dan kerja. Kata communio, dalam kata kerja communicate, yang artinya membagi sesuatu dengan seseorang, tukar menukar, membicarakan sesuatu dengan orang, bercakap-cakap bertukar pikiran, berhubungan, berteman (Nurjaman dan Umam, 2014:35).

Komunikasi merupakan transmisi informasi, gagasan, emosi, keterampilan, dan sebagainya dengan menggunakan simbol, kata, grafik, dan sebagainya. Tidakan atau proses transmisi itulah yang biasa disebut komunikasi (Bernard Berelson dan Gary A. Steiner dalam Mulyana, 2013: 68).

Meskipun semua organisasi harus melakukan komunikasi dengan berbagai pihak dalam mencapai tujuannya, perlu diketahui bahw apendekatan yang dipakai anatara suatu organisasi dengan organisasi lain dapat bervariasi atau berbeda-beda, yaitu: 1 . Komunikasi dari atas ke bawah, 2. Komunikasi dari 
bawah ke atas, 3. Komunikasi horizontal dan 4. Komunikasi diagonal (Purwanto, 2013:49).

\section{METODE PENELITIAN DAN PEMBAHASAN}

\section{A. Pendekatan Penelitian}

Penelitian kuantitatif yaitu studi yang diposisikan sebagai variabel bebas nilai (value free), selain itu lain penelitian kuantitatif sangat ketat menerapkan prinsip-prinsip objektivitas. Objektivitas itu diperoleh antara lain melalui penggunaan instrumen yang telah diuji validitasnya dan reliabilitasnya.

Menurut Sugiyono (2016:8) mengartikan metode kuantitatif sebagai metode penelitian yang berlandaskan pada filsafat positivisme, digunakan untuk meneliti pada populasi atau sampel tertentu, pengumpulan data menggunakan instrumen penelitian, analisis data bersifat kuantitatif/statistik, dengan tujuan untuk menjawab hipotesis yang telah ditetapkan.

\section{B. Populasi Dan Sampel Populasi}

Menurut Sugiyono (2016:80) populasi bukan hanya orang, tetapi juga obyek dan dan benda-benda alam lainnya. Populasi bukan sekedar jumlah yang ada pada obyek/subyek yang dipelajari, tetapi meliputi seluruh karakteristik atau sifat yang dimiliki oleh subyek atau obyek itu. Populasi yang ada di PT. Woneel Midas Leathers sebanyak 200.

\section{Sampel}

Menurut Sugiyono (2016:81) Sampel adalah bagian dari jumlah dan karakteristik yang dimiliki oleh populasi tersebut. Dalam menentukan jumlah sample, penulis menggunakan rumus dari Slovin sebagai berikut:

$$
\mathrm{n}=\frac{N}{1+N e^{2}}
$$

Juliansyah Noor (2015:157)

Keterangan:

$\mathrm{n}=$ Jumlah Sample

$N=$ Jumlah Populasi

$\mathrm{e}=$ Taraf Kesalahan $10 \%$

$$
\mathrm{n}=\frac{200}{1+200.0,01}
$$

$$
\begin{gathered}
n=\frac{200}{3} \\
n=66,6666666667
\end{gathered}
$$

Dibulatkan menjadi 67

Maka jumlah sample yang digunakan sebanyak 67 orang dengan taraf kesalahan $10 \%$. Pengambian sample dilakukan dengan teknik sampling insidental, yaitu teknik penentuan sample berdasarkan kebetulan, yaitu siapa saja yang secara kebetulan/insidental bertemu dengan peneliti dapat dijadikan sebagai sample, bila dipandang kebetulan ditemui itu sesuai sebagai sumber data (Sugiyono, 2016:85).

\section{Metode Pengumpulan Data}

Metode pengumpulan data yang di gunakan dalam penelitian ini menggunakan kuesioner sebagai alat pengumpulan data pokok. Daftar pertanyaan atau kuesioner dalam penelitian ini diukur menggunakan Skala Likert menggunakan lima skala sebagai berikut:

1. Sangat setuju : skor $=5$

2. Setuju : skor $=4$

3. Ragu-ragu : skor $=3$

4. Tidak setuju $:$ skor $=2$

5. Sangat tidak setuju : skor $=1$

\section{Analisis Data dan Pembahasan}

\section{Analisis Statistik Deskriptif}

\section{a. Identitas Responden}

Responden dalam penelitian ini adalah karyawan PT. Woneel Midas Leathers Departemen Produksi dengan menyebarkan kuesioner secara Kebetulan atau Sampling insidental yang seluruhnya berjumlah 67 orang.

\section{1) Jenis Kelamin}

Dari 67 orang responden, 46 orang adalah responden Perempuan dan sisanya yaitu 21 orang adalah responden Laki-laki. Identitas responden berdasarkan jenis kelamin secara ringkas telah dirangkum dalam tabel 4.1 dibawah ini :

\section{Tabel 4.1}

Responden Dirinci Menurut Jenis Kelamin

\begin{tabular}{|l|l|l}
\hline Jenis Kelamin & Jumlah & Persentase \%
\end{tabular}




\begin{tabular}{|c|c|c|} 
Perempuan & 46 Orang & $69 \%$ \\
\hline Laki-laki & 21 Orang & $31 \%$ \\
\hline Jumlah & 67 Orang & $100 \%$ \\
\hline
\end{tabular}

Sumber : Data primer yang diolah, 2018

Identitas responden berdasarkan jenis kelamin juga disajikan dalam bentuk gambar yang dapat dilihat pada gambar 4.2.

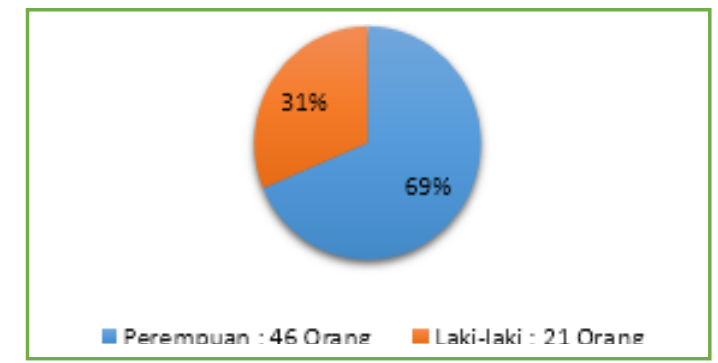

Sumber Data: Data Primer yang Diolah, 2018

Gambar 4.2

Pie Chart Responden Menurut Jenis Kelamin

2) Masa Kerja

Responden yang memiliki masa kerja pada rentang 1 hingga 5 tahun sebanyak 47 orang. Responden yang memiliki masa kerja pada rentang 5 hingga 10 tahun sebanyak 18 orang. Responden yang memiliki masa kerja pada rentang 10 hingga 20 tahun sebanyak 2 orang. Identitas responden berdasarkan masa kerja secara ringkas telah dirangkum dalam Tabel 4.2 dan gambar 4.3.

Tabel 4.2

Responden Dirinci Berdasarkan Masa Kerja

\begin{tabular}{|c|c|c|}
\hline $\begin{array}{c}\text { Masa Kerja } \\
\text { (Tahun) }\end{array}$ & $\begin{array}{c}\text { Jumlah } \\
\text { Karyawan }\end{array}$ & Persentase \\
\hline $1-5$ & 47 & $70 \%$ \\
\hline $5-10$ & 18 & $27 \%$ \\
\hline $10-20$ & 2 & $3 \%$ \\
\hline Jumlah & 67 & $100 \%$ \\
\hline
\end{tabular}

Sumber : Data primer yang diolah, 2018

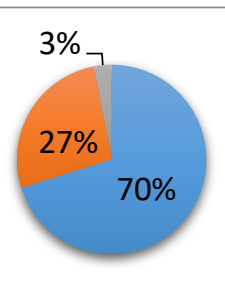

1-5 tahun 47 Orang

5-10 tahun 18 Orang 10-20tahun 2 Orang

\section{b. Analisis Deskriptif Variabel}

1) Variabel Beban Kerja

Analisis deskriptif Beban Kerja yang ada di PT. Woneel Midas Leathers.

Tabel 4.3

\begin{tabular}{|c|c|c|c|c|c|c|c|}
\hline \multirow[b]{2}{*}{ Variabel } & \multirow[b]{2}{*}{ Pertanyaan } & \multicolumn{5}{|c|}{ Point } & \multirow[b]{2}{*}{$\sum$} \\
\hline & & $\begin{array}{c}\text { Sangat } \\
\text { Tidak } \\
\text { Setuju }\end{array}$ & $\begin{array}{l}\text { Tidak } \\
\text { Setuju }\end{array}$ & $\begin{array}{l}\text { Ragu } \\
\text { Ragu }\end{array}$ & Setuju & $\begin{array}{l}\text { Sangat } \\
\text { Setuju }\end{array}$ & \\
\hline \multirow{10}{*}{$\begin{array}{c}\text { Beban } \\
\text { Kerja } \\
\left(\mathrm{X}_{1}\right)\end{array}$} & 1 & 2 & 1 & 1 & 42 & 21 & 67 \\
\hline & 2 & 0 & 15 & 16 & 27 & 9 & 67 \\
\hline & 3 & 0 & 7 & 5 & 48 & 7 & 67 \\
\hline & 4 & 5 & 28 & 12 & 16 & 6 & 67 \\
\hline & 5 & 0 & 8 & 7 & 44 & 8 & 67 \\
\hline & 6 & 0 & 8 & 7 & 44 & 8 & 67 \\
\hline & 7 & 0 & 5 & 7 & 43 & 12 & 67 \\
\hline & 8 & 1 & 1 & 4 & 51 & 10 & 67 \\
\hline & 9 & 1 & 1 & 2 & 37 & 26 & 67 \\
\hline & 10 & 0 & 1 & 2 & 50 & 14 & 67 \\
\hline
\end{tabular}

Hasil Perhitungan Kuesioner Beban Kerja

Jawaban kuesioner juga disajikan dalam bentuk diagram histogram yang dapat dilihat pada gambar 4.4.

\begin{tabular}{|c|c|c|c|c|c|c|c|c|c|c|}
\hline \multirow{3}{*}{$\begin{array}{r}60 \\
50 \\
40 \\
30 \\
20 \\
10 \\
0\end{array}$} & & & & & & & & \multirow{2}{*}{\multicolumn{2}{|c|}{$\square$}} & \multirow{2}{*}{-} \\
\hline & 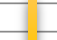 & & & & & & & & & \\
\hline & 1 & 2 & 3 & 4 & 5 & 6 & 7 & 8 & 9 & 10 \\
\hline $\begin{array}{c}\text { Sangat Tidak } \\
\text { Setuju }\end{array}$ & 2 & 0 & 0 & 5 & 0 & 0 & 0 & 1 & 1 & 0 \\
\hline Tidak Setuju & 1 & 15 & 7 & 28 & 8 & 8 & 5 & 1 & 1 & 1 \\
\hline Ragu-Ragu & 1 & 16 & 5 & 12 & 7 & 7 & 7 & 4 & 2 & 2 \\
\hline Setuju & 42 & 27 & 48 & 16 & 44 & 44 & 43 & 51 & 37 & 50 \\
\hline Sangat Setuju & 21 & 9 & 7 & 6 & 8 & 8 & 12 & 10 & 26 & 14 \\
\hline
\end{tabular}

Sumber : Data Primer yang Diolah, 2018

Gambar 4.4

Histogram Perhitungan Jawaban Kuesioner Beban Kerja

Berdasarkan gambar 4.4 dapat diketahui bahwa penilaian tertinggi yang diberikan oleh responden untuk kuisioner Beban Kerja ada pada butir pernyataan nomor 10 yaitu "Saya berusaha menyelesaikan pekerjaan sebelum batas waktu yang telah ditentukan oleh perusahaan.", dengan skor yang diperoleh sebesar 64. Untuk penilaian terendah ada pada butir pernyataan nomor 4 yaitu "Saya melebihi batas waktu dalam menjalankan 
pekerjaan", dengan skor yang diperoleh

Tabel 4.5 sebesar 33 .

\section{2) Variabel Komunikasi}

Analisis deskriptif variabel Komunikasi dilakukan untuk memetakan Komunikasi perusahaan menurut karyawan di PT. Woneel Midas Leathers.

Tabel 4.4

Hasil Perhitungan Kuisioner Komunikasi

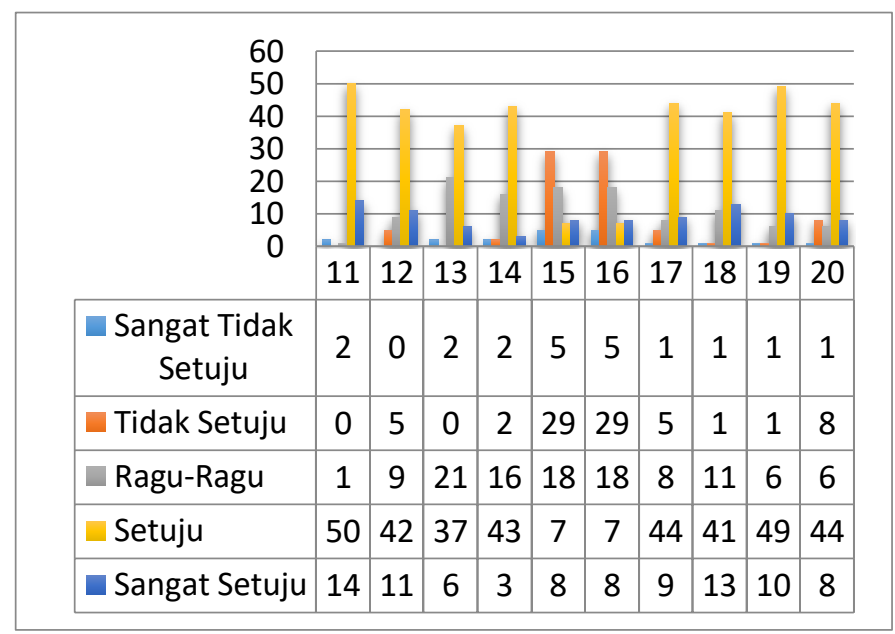

Sumber : Data Primer yang Diolah, 2018

oGambar 4.5

Histogram Perhitungan Jawaban Kuisioner Komunikasi

Berdasarkan gambar 4.5 dapat diketahui bahwa penilaian tertinggi yang diberikan oleh responden untuk kuisioner Komunikasi ada pada butir pernyataan nomor 11 yaitu "Setiap kendala pekerjaan yang terjadi saya komunikasikan kepada atasan", dan "Saya tidak berani menyampaikan informasi ke atasan", dengan skor yang diperoleh sebesar 64. Untuk penilaian terendah ada pada butir pernyataan nomor 15 dan 16 yaitu "Saya tidak dapat menyelesaikan tugas dengan baik", dengan skor yang diperoleh sebesar 34 .

\section{3) Variabel Produktivitas Kerja}

Analisis deskriptif variabel produktivitas kerja dilakukan untuk melihat skor tertinggi dan terendah yang diberikan oleh responden terhadap pernyataan dalam kuesioner. Analisis produktivitas kerja telah dirangkum dalam tabel 4.5 dan gambar 4.6.

\begin{tabular}{|c|c|c|c|c|c|c|c|}
\hline \multirow[b]{2}{*}{ Variabel } & \multirow{2}{*}{$\begin{array}{l}\text { Item } \\
\text { Perta- } \\
\text { nyaan }\end{array}$} & \multicolumn{5}{|c|}{ Point } & $\sum$ \\
\hline & & $\begin{array}{l}\text { Sangat } \\
\text { Tidak } \\
\text { Setuju }\end{array}$ & $\begin{array}{l}\text { Tidak } \\
\text { Setuju }\end{array}$ & $\begin{array}{l}\text { Ragu } \\
\text { Ragu }\end{array}$ & Setuju & $\begin{array}{l}\text { Sangat } \\
\text { Setuju }\end{array}$ & \\
\hline \multirow{10}{*}{$\begin{array}{c}\text { Komuni- } \\
\text { kasi } \\
\text { (X2) }\end{array}$} & 1 & 2 & 0 & 1 & 50 & 14 & 67 \\
\hline & 2 & 0 & 5 & 9 & 42 & 11 & 67 \\
\hline & 3 & 2 & 0 & 21 & 37 & 6 & 66 \\
\hline & 4 & 2 & 2 & 16 & 43 & 3 & 66 \\
\hline & 5 & 5 & 29 & 18 & 7 & 8 & 67 \\
\hline & 6 & 5 & 29 & 18 & 7 & 8 & 67 \\
\hline & 7 & 1 & 5 & 8 & 44 & 9 & 67 \\
\hline & 8 & 1 & 1 & 11 & 41 & 13 & 67 \\
\hline & 9 & 1 & 1 & 6 & 49 & 10 & 67 \\
\hline & 10 & 1 & 8 & 6 & 44 & 8 & 67 \\
\hline
\end{tabular}

Hasil Perhitungan Kuisioner Produktivitas Kerja

\begin{tabular}{|c|c|c|c|c|c|c|c|}
\hline \multirow[b]{2}{*}{ Variabel } & \multirow[b]{2}{*}{$\begin{array}{l}\text { Item } \\
\text { Perta- } \\
\text { nyaan }\end{array}$} & \multicolumn{5}{|c|}{ Point } & $\sum$ \\
\hline & & $\begin{array}{l}\text { Sangat } \\
\text { Tidak } \\
\text { Setuju }\end{array}$ & $\begin{array}{l}\text { Tidak } \\
\text { petuju }\end{array}$ & $\begin{array}{l}\text { Ragu } \\
\text { Ragu }\end{array}$ & Setuju & $\begin{array}{l}\text { Sangat } \\
\text { Setuju }\end{array}$ & \\
\hline \multirow{10}{*}{$\begin{array}{c}\text { Produk- } \\
\text { tivitas } \\
\text { Kerja } \\
(\mathrm{Y})\end{array}$} & 1 & 0 & 0 & 9 & 55 & 3 & 67 \\
\hline & 2 & 0 & 12 & 15 & 26 & 14 & 67 \\
\hline & 3 & 0 & 0 & 13 & 44 & 9 & 66 \\
\hline & 4 & 0 & 0 & 1 & 41 & 25 & 67 \\
\hline & 5 & 0 & 6 & 22 & 26 & 13 & 67 \\
\hline & 6 & 0 & 6 & 22 & 26 & 13 & 67 \\
\hline & 7 & 1 & 17 & 13 & 29 & 7 & 67 \\
\hline & 8 & 2 & 0 & 2 & 44 & 19 & 67 \\
\hline & 9 & 0 & 4 & 10 & 41 & 12 & 67 \\
\hline & 10 & 0 & 1 & 9 & 52 & 5 & 67 \\
\hline
\end{tabular}

Sumber : Data primer yang diolah, 2018

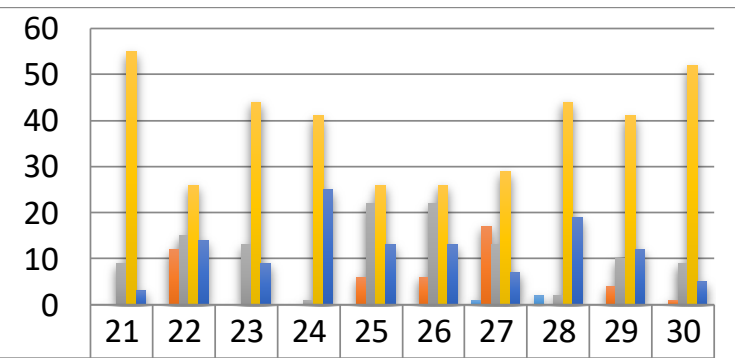

\begin{tabular}{|l|c|c|c|c|c|c|c|c|c|c|}
\hline $\begin{array}{c}\text { Sangat Tidak } \\
\text { Setuju }\end{array}$ & 0 & 0 & 0 & 0 & 0 & 0 & 1 & 2 & 0 & 0 \\
\hline - Tidak Setuju & 0 & 12 & 0 & 0 & 6 & 6 & 17 & 0 & 4 & 1 \\
\hline Ragu-Ragu & 9 & 15 & 13 & 1 & 22 & 22 & 13 & 2 & 10 & 9 \\
\hline Setuju & 55 & 26 & 44 & 41 & 26 & 26 & 29 & 44 & 41 & 52 \\
\hline - Sangat Setuju & 3 & 14 & 9 & 25 & 13 & 13 & 7 & 19 & 12 & 5 \\
\hline
\end{tabular}

Sumber: Data Primer yang Diolah, 2018

Gambar 4.6

Histogram Perhitungan Jawaban Kuisioner Produktivitas Kerja 
Berdasarkan gambar 4.6 dapat diketahui bahwa penilaian tertinggi yang diberikan oleh responden untuk kuisioner Produktivitas Kerja ada pada butir pernyataan nomor 24 yaitu "Saya selalu berusaha meningkatkan kualitas kerja saya", dengan skor yang diperoleh masing-masing sebesar 66. Untuk penilaian terendah ada pada butir pernyataan nomor 27 yaitu "Terkadang saya merasa jenuh terhadap pekerjaan yang saya tangani”, dengan skor yang diperoleh sebesar 18 .

\section{Analisis Statistik Inferensial}

\section{a. Uji Validitas dan Reliabilitas Instrumen 1) Uji Validitas}

Dalam melakukan pengujian validitas instrumen, penulis menggunakan bantuan program SPSS versi 24. Hal tersebut dilakukan mengingat banyaknya butir yang digunakan pada kuesioner penelitian. Butir pernyataan yang dinyatakan valid apabila $r$ hitung $>\mathrm{r}$ tabel nilai $\mathrm{df}=\mathrm{n}-2$. Nilai $\mathrm{r}$ tabel dengan $\alpha=10 \%$ dan $\mathrm{n}=67$ atau nilai $\mathrm{df}=$ $67-2=65$ adalah sebesar 0,202.

Hasil pengujian validitas seluruh variabel telah dirangkum dalam tabel 4.6, 4.7, dan 4.8.

Tabel 4.6

Uji Validitas Instrumen Beban Kerja

\begin{tabular}{|c|c|c|c|}
\hline $\begin{array}{c}\text { No Item } \\
\text { Pertanyaan }\end{array}$ & $\begin{array}{c}\mathbf{R} \\
\text { Hitung }\end{array}$ & $\begin{array}{c}\mathbf{R} \\
\text { Tabel }\end{array}$ & Keterangan \\
\hline Pernyataan 1 & 0,709 & 0,202 & Valid \\
\hline Pernyataan 2 & 0,409 & 0,202 & Valid \\
\hline Pernyataan 3 & 0,440 & 0,202 & Valid \\
\hline Pernyataan 4 & 0,238 & 0,202 & Valid \\
\hline Pernyataan 5 & 0,225 & 0,202 & Valid \\
\hline Pernyataan 6 & 0,390 & 0,202 & Valid \\
\hline Pernyataan 7 & 0,583 & 0,202 & Valid \\
\hline Pernyataan 8 & 0,687 & 0,202 & Valid \\
\hline Pernyataan 9 & 0,673 & 0,202 & Valid \\
\hline Pernyataan 10 & 0,598 & 0,202 & Valid \\
\hline
\end{tabular}

Sumber : hasil Pengelolahan Data SPSS 24

Berdasarkan dari tabel 4.6 diatas hasil uji pengolahan data dapat diketahui bahwa semua pernyataan pada kuesioner dinyatakan validitas, karena $r_{\text {hitung }}>0,202$ maka semua pernyataan dapat digunakan sebagai alat pengumpulan data.
Uji Validitas Instrumen Komunikasi

\begin{tabular}{|c|c|c|c|}
\hline $\begin{array}{c}\text { No Item } \\
\text { Pertanyaan }\end{array}$ & $\begin{array}{c}\mathbf{R} \\
\text { Hitung }\end{array}$ & $\begin{array}{c}\mathbf{R} \\
\text { Tabel }\end{array}$ & Keterangan \\
\hline Pernyataan 1 & 0,626 & 0,202 & Valid \\
\hline Pernyataan 2 & 0,592 & 0,202 & Valid \\
\hline Pernyataan 3 & 0,499 & 0,202 & Valid \\
\hline Pernyataan 4 & 0,478 & 0,202 & Valid \\
\hline Pernyataan 5 & 0,317 & 0,202 & Valid \\
\hline Pernyataan 6 & 0,236 & 0,202 & Valid \\
\hline Pernyataan 7 & 0,612 & 0,202 & Valid \\
\hline Pernyataan 8 & 0,665 & 0,202 & Valid \\
\hline Pernyataan 9 & 0,542 & 0,202 & Valid \\
\hline Pernyataan 10 & 0,534 & 0,202 & Valid \\
\hline
\end{tabular}

Sumber : hasil Pengelolahan Data SPSS 24

Berdasarkan dari tabel 4.7 diatas hasil uji pengolahan data dapat diketahui bahwa semua pernyataan pada kuesioner dinyatakan validitas, karena $r_{\text {hitung }}>$ 0,202 maka semua pernyataan dapat digunakan sebagai alat pengumpulan data.

Tabel 4.8

Uji Validitas Instrumen Produktivitas Kerja

\begin{tabular}{|c|c|c|c|}
\hline $\begin{array}{c}\text { No Item } \\
\text { Pertanyaan }\end{array}$ & $\begin{array}{c}\mathbf{R} \\
\text { Hitung }\end{array}$ & $\begin{array}{c}\mathbf{R} \\
\text { Tabel }\end{array}$ & Keterangan \\
\hline Pernyataan 1 & 0,643 & 0,202 & Valid \\
\hline Pernyataan 2 & 0,501 & 0,202 & Valid \\
\hline Pernyataan 3 & 0,522 & 0,202 & Valid \\
\hline Pernyataan 4 & 0,421 & 0,202 & Valid \\
\hline Pernyataan 5 & 0,541 & 0,202 & Valid \\
\hline Pernyataan 6 & 0,556 & 0,202 & Valid \\
\hline Pernyataan 7 & 0,301 & 0,202 & Valid \\
\hline Pernyataan 8 & 0,577 & 0,202 & Valid \\
\hline Pernyataan 9 & 0,531 & 0,202 & Valid \\
\hline Pernyataan 10 & 0,495 & 0,202 & Valid \\
\hline Sumber:
\end{tabular}

Sumber : hasil Pengelolahan Data SPSS 24

Berdasarkan dari tabel 4.8 diatas hasil uji pengolahan data dapat diketahui bahwa semua pernyataan pada kuesioner dinyatakan validitas, karena $r_{\text {hitung }}>0,202$ maka semua pernyataan dapat digunakan sebagai alat pengumpulan data.

\section{1) Uji Reliabilitas}

\section{Pengujian}

reliabilitas

dalam penentuan tingkat reliabilitas suatu instrument penelitian dapat diterima bila 
memiliki koefisien alpha lebih besar dari 0,6 . Berikut ini hasil dari uji reliabilitas :

Tabel 4.9

Hasil Uji Reliabilitas Variabel Beban Kerja Reliability Statistics

\begin{tabular}{|r|r|}
\hline $\begin{array}{c}\text { Cronbach's } \\
\text { Alpha }\end{array}$ & N of Items \\
\hline .604 & 10 \\
\hline
\end{tabular}

Sumber Data: Data primer yang diolah menggunakan SPSS versi 24

Berdasarkan tabel 4.9 dalam uji reliabilitas diketahui bahwa nilai Alpha Cronbach's > 0,6 yakni $(0,604>0,6)$ maka, kuesioner tersebut dinamakan reliabel.

Tabel 4.10

Hasil Uji Reliabilitas Variabel Komunikasi Reliability Statistics

\begin{tabular}{|c|r|}
\hline $\begin{array}{c}\text { Cronbach' } \\
\text { s Alpha }\end{array}$ & $\begin{array}{c}\text { N of } \\
\text { Items }\end{array}$ \\
\hline .619 & 10 \\
\hline
\end{tabular}

Sumber Data: Data primer yang diolah menggunakan SPSS versi 24

Berdasarkan tabel 4.10 dalam uji reliabilitas diketahui bahwa nilai Alpha Cronbach's > 0,6 yakni $(0,619>0,6)$ maka, kuesioner tersebut dinamakan reliabel.

Tabel 4.11

Hasil Uji Reliabilitas Variabel Produktivitas Kerja Reliability Statistics

\begin{tabular}{|r|r|}
\hline $\begin{array}{c}\text { Cronbach's } \\
\text { Alpha }\end{array}$ & N of Items \\
\hline .737 & 10 \\
\hline
\end{tabular}

Sumber Data: Data primer yang diolah menggunakan SPSS versi 24

Berdasarkan tabel 4.11 dalam uji reliabilitas diketahui bahwa nilai Alpha Cronbach's > 0,6 yakni $(0,737>0,6)$ maka, kuesioner tersebut dinamakan reliabel.

\section{Analisis Regresi Sederhana dan Berganda.}

a. Analisis Regresi Sederhana

1) Koefisien Regresi Sederhana Beban Kerja $\left(\mathbf{X}_{1}\right)$ terhadap Produktivitas $\operatorname{Kerja}(\mathbf{Y})$

Koefisien regresi sederhana dalam penelitian ini bertujuan untuk mengetahui bagaimana pengaruh yang terjadi pada Produktivitas Kerja apabila Beban Kerja mengalami perubahan.

Hasil analisis koefisien regresi sederhana telah diringkas dalam tabel 4.12 .

Tabel 4.12

Koefisien Regresi Sederhana $X_{1} Y$

\begin{tabular}{|c|c|c|c|c|c|c|}
\hline \multicolumn{7}{|c|}{ Coefficients $^{a}$} \\
\hline & & \multicolumn{2}{|c|}{$\begin{array}{c}\text { Unstandardized } \\
\text { Coefficients }\end{array}$} & \multirow[t]{2}{*}{$\begin{array}{l}\text { Standardized } \\
\text { Coefficients }\end{array}$} & \multirow[b]{2}{*}{$\mathrm{T}$} & \multirow[b]{2}{*}{ Sig. } \\
\hline Model & & $\mathrm{B}$ & $\begin{array}{l}\text { Std. } \\
\text { Error }\end{array}$ & & & \\
\hline \multirow[t]{2}{*}{1} & (Constant) & 22.550 & 4.521 & & 4.988 & .000 \\
\hline & Beban Kerja & .441 & .122 & .409 & 3.612 & .001 \\
\hline
\end{tabular}

a. Dependent Variable: Produktivitas Kerja

Sumber: hasil Pengelolahan Data SPSS 24

Berdasarkan tabel 4.12 dapat diketahui bahwa koefisien regresi sederhana yang didapat adalah $\mathrm{Y}=22,550$ $+0,441 X_{1}$.

Penjelasan persamaan tersebut adalah sebagai berikut :

a) Konstanta sebesar 22,550 artinya jika Beban Kerja nilainya 0, maka tingkat Produktivitas Kerja nilainya sebesar 22,550.

b) Koefisien regresi Beban Kerja sebesar 0,441 artinya apabila Beban Kerja meningkat sebesar 1 poin, maka Produktivitas Kerja akan meningkat sebesar 0,441 poin. Sebaliknya, apabila Beban Kerja mengalami penurunan sebesar 1 poin, maka Produktivitas Kerja akan menurun sebesar 0,441 poin, Jika nilai $\mathrm{X}_{1}=0$, maka $\mathrm{Y}=$ 22,550

\section{2) Koefisien Regresi Sederhana Komunikasi $\left(\mathbf{X}_{2}\right) \quad$ terhadap Produktivitas Kerja (Y).}

Hasil analisis koefisien regresi sederhana Komunikasi terhadap Produktivitas Kerja telah diringkas dalam tabel 4.13

Tabel 4.13

Koefisien Regresi Sederhana $\mathrm{X}_{2} \mathrm{Y}$ 


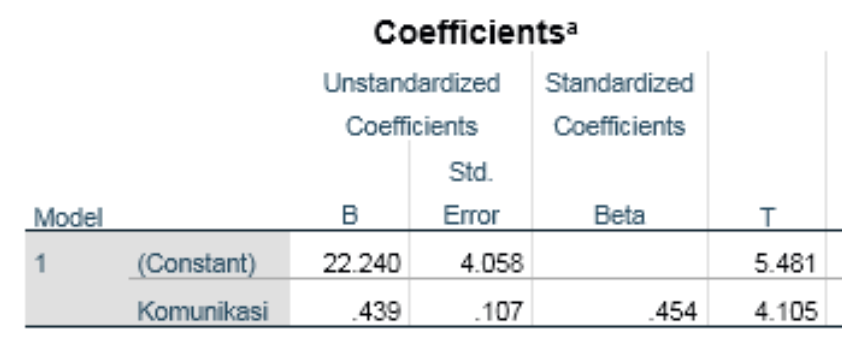

a. Dependent Variable: Produktivitas Kerja

Sumber: hasil Pengelolahan Data SPSS 24

Berdasarkan tabel 4.13 dapat diketahui bahwa koefisien regresi sederhana yang didapat adalah $\mathrm{Y}=22,240$ $+0,439 X_{2}$. Penjelasan persamaan tersebut adalah sebagai berikut :

a) Konstanta sebesar 22,240 artinya jika Komunikasi nilainya 0 , maka tingkat Produktivitas Kerja nilainya sebesar 22,240 .

b) Koefisien regresi Komunikasi sebesar 0,439 artinya apabila penilaian prestasi kerja meningkat sebesar 1 poin, maka produktivitas kerja akan meningkat sebesar 0,439 poin. Sebaliknya, apabila Komunikasi mengalami penurunan sebesar 1 poin, maka produktivitas kerja akan menurun sebesar 0,439 poin, Jika nilai $X_{2}=0$, maka $Y=22,240$.

\section{b. Analisis Regresi Berganda}

Koefisien regresi linier berganda dalam penelitian ini bertujuan untuk mengetahui bagaimana pengaruh yang terjadi pada Produktivitas Kerja Karyawan apabila Beban Kerja dan Komunikasi mengalami perubahan. Hasil analisis koefisien regresi linier berganda telah diringkas dalam tabel 4.14.

Tabel 4.14

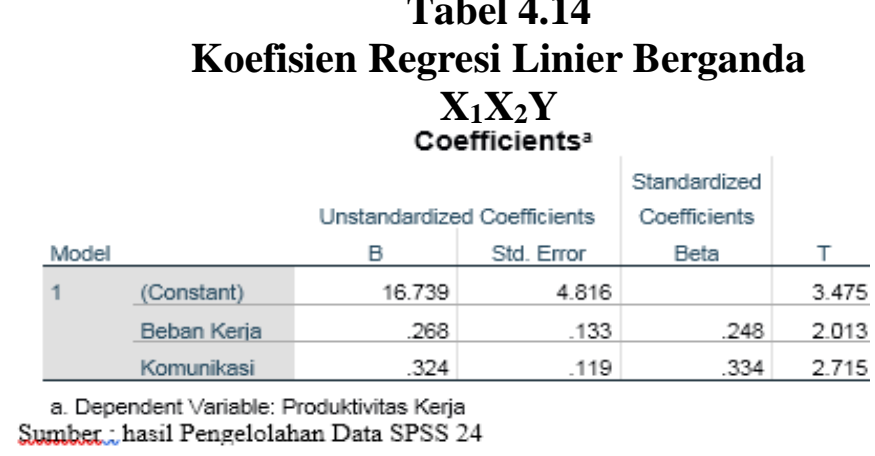
Berdasarkan tabel 4.14 dapat
diketahui bahwa koefisien regresi linier

berganda yang didapat adalah $\mathrm{Y}=16,739+$ $0.268 \mathrm{X}_{1}+0.324 \mathrm{X}_{2}$

Artinya, apabila Beban Kerja meningkat 1 poin dengan asumsi Komunikasi tidak berubah, maka Produktivitas Kerja akan meningkat sebesar 0.268 poin.

Selanjutnya, apabila Komunikasi meningkat sebesar 1 poin dengan asumsi Produktivitas Kerja tidak berubah, maka Produktivitas Kerja akan meningkat sebesar 0.324 poin. Sebaliknya, apabila terjadi penurunan pada Beban Kerja dan Komunikasi, maka Produktivitas Kerja juga akan ikut mengalami penurunan. Pengaruh yang demikian disebut dengan pengaruh yang searah.

\section{Analisis Korelasi Sederhana dan Berganda.}

Menurut Sugiyono (2016:184), pedoman untuk memberikan interpretasi koefisien korelasi ada dalam tabel 4.15 dibawah ini:

Tabel 4.15

Nilai Korelasi

\begin{tabular}{|c|c|}
\hline 0,00 hingga 0,199 & sangat rendah \\
\hline 0,20 hingga 0,399 & Rendah \\
\hline 0,40 hingga 0,599 & Sedang \\
\hline 0,60 hingga 0,799 & Kuat \\
\hline 0,80 hingga 1,000 & sangat kuat \\
\hline
\end{tabular}

\section{a. Analisis Korelasi Sederhana}

1) Koefisien Korelasi Variabel Beban Kerja (X1) terhadap Produktivitas Kerja (Y)

Hasil pengelolaan data menggunakan metode komputerisasi program SPSS 24, hasil perhitungan koefisien korelasi dirangkum dalam tabel 4.16 sebagai berikut :

Tabel 4.16

Koefisien Korelasi $X_{1} Y$ 


\section{Correlations}

\begin{tabular}{llr|r} 
& & Beban Kerja & \multicolumn{1}{c}{$\begin{array}{c}\text { Produktivitas } \\
\text { Kerja }\end{array}$} \\
\hline \multirow{2}{*}{ Beban Kerja } & Pearson Correlation & 1 & $.409^{\circ}$ \\
\cline { 2 - 4 } & Sig. (2-tailed) & & .001 \\
\cline { 2 - 4 } & $\mathrm{N}$ & 67 & 67 \\
\hline \multirow{2}{*}{ Produktivitas Kerja } & Pearson Correlation & $.409^{\circ}$ & 1 \\
\cline { 2 - 4 } & Sig. (2-tailed) & .001 & \\
\cline { 2 - 4 } & $\mathrm{N}$ & 67 & 67 \\
\hline
\end{tabular}

*t. Correlation is siqnificant at the 0.01 level (2-tailed).

Sumber: hasil Pengelolahan Data SPSS 24

Berdasarkan tabel 4.16 dapat diketahui bahwa, koefisien korelasi variabel beban kerja dengan produktivitas kerja adalah sebesar 0,409. Angka tersebut apabila dikonsultasikan pada pedoman penentuan intepretasi yang dikemukakan oleh Sugiyono, maka hubungan antara variabel Beban Kerja terhadap Produktivitas Kerja dalam penelitian ini termasuk dalam kategori Sedang.

\section{2) Koefisien Korelasi Variabel Komunikasi (X2) terhadap Produktivitas Kerja (Y)}

Hasil perhitungan koefisien korelasi Komunikasi dengan Produktivitas Kerja telah dirangkum dalam tabel 4.17 dibawah ini :

\section{Tabel 4.17}

\section{Koefisien Korelasi $\mathrm{X}_{2} \mathrm{Y}$ Correlations}

\begin{tabular}{llr|r} 
& & $\begin{array}{c}\text { Produktivitas } \\
\text { Kerja }\end{array}$ & Komunil \\
\hline Produktivitas Kerja & Pearson Correlation & 1 & \\
\cline { 2 - 4 } & Sig. (2-tailed) & & \\
\cline { 2 - 4 } & $\mathrm{N}$ & 67 & \\
\hline \multirow{2}{*}{ Komunikasi } & Pearson Correlation & .454 & \\
\cline { 2 - 4 } & Sig. (2-tailed) & .000 & \\
\cline { 2 - 4 } & $\mathrm{N}$ & 67 & \\
\hline
\end{tabular}

*. Correlation is siqnificant at the 0.01 level (2-tailed).

Sumber: hasil Pengelolahan Data SPSS 24

Berdasarkan tabel 4.17, dapat diketahui bahwa, koefisien korelasi variabel Komunikasi dengan Produktivitas Kerja adalah sebesar 0.454. Angka tersebut apabila dikonsultasikan pada pedoman penentuan intepretasi yang dikemukakan oleh Sugiyono, maka hubungan antara variabel komunikasi dan produktivitas kerja dalam penelitian ini termasuk dalam kategori sedang.

\section{b. Koefisien Korelasi Berganda}

Hasil perhitungan koefisien korelasi berganda telah dirangkum dalam tabel 4.18.

Tabel 4.18

Koefisien Korelasi $\mathrm{X}_{1} \mathrm{X}_{2} \mathrm{Y}$ Model Summary

\begin{tabular}{lr|r|r|r} 
Model & R & R Square & \multicolumn{1}{c|}{$\begin{array}{c}\text { Adjusted R } \\
\text { Square }\end{array}$} & $\begin{array}{l}\text { Std. Error of the } \\
\text { Estimate }\end{array}$ \\
\hline 1 & $.503^{\mathrm{a}}$ & .253 & .230 & 3.66187 \\
\hline
\end{tabular}

a. Predictors: (Constant), Komunikasi, Beban Kerja Sumber hasil Pengelolahan Data SPSS 24

Berdasarkan tabel 4.18, dapat diketahui bahwa koefisien korelasi berganda variabel Beban Kerja dan Komuikasi dengan Produktivitas Kerja adalah sebesar 0.503. Angka tersebut apabila dikonsultasikan pada pedoman penentuan intepretasi yang dikemukakan oleh Sugiyono, maka hubungan antara variabel Beban Kerja dan Komunikasi dengan Produktivitas Kerja dalam penelitian ini termasuk dalam kategori Sedang.

\section{Uji Koefisien Determinasi (KD)}

Rumusnya untuk mencari nilai koefisien determinasi adalah sebagai berikut:

$$
\mathrm{KD}=(\mathrm{r})^{2} \mathrm{X}
$$

\section{a. Koefisien Determinasi Variabel Beban Kerja (X1) terhadap Produktivitas Kerja (Y)}

Berdasarkan perhitungan SPSS, maka hasil perhitungan dapat dilihat pada tabel 4.19 dibawah ini:

Tabel 4.19

Koefisien Determinasi $\mathrm{X}_{1} \mathrm{Y}$ Model Summary

\begin{tabular}{l|l|l} 
R & Adjusted & Std. Error of
\end{tabular} \begin{tabular}{ll|l|l|l} 
Model R & Square & R Square the Estimate
\end{tabular}

\begin{tabular}{lllll}
\hline 1 & $.409^{\mathrm{a}}$ & .167 & .154 & 3.83708 \\
\hline
\end{tabular}

a. Predictors: (Constant), Beban Kerja

Sumber : hasil Pengelolahan Data SPSS 24

Berdasarkan tabel 4.19 angka koefisien determinasi yang didapat adalah sebesar 
0.167. angka tersebut apabila dikalikan dengan $100 \%$ maka hasil yang didapat adalah sebesar $16,70 \%$. Artinya, kontribusi yang diberikan Beban Kerja terhadap Produktivitas Kerja adalah sebesar 16,70\%, sedangkan sisanya sebesar $83,30 \%$ ditentukan oleh variabel lain yang tidak diteliti.

\section{b. Koefisien Determinasi Variabel Komunikasi (X2) terhadap Produktivitas Kerja (Y)}

Berdasarkan perhitungan SPSS, maka hasil perhitungan dapat dilihat pada tabel 4.20 dibawah ini :

Tabel 4.20

\section{Koefisien Determinasi $\mathrm{X}_{2} \mathrm{Y}$} Model Summary

\begin{tabular}{ll|r|r|r} 
Model & $\mathrm{R}$ & $\begin{array}{c}\mathrm{R} \\
\text { Square }\end{array}$ & $\begin{array}{c}\text { Adjusted } \\
\text { R Square }\end{array}$ & $\begin{array}{l}\text { Std. Error of } \\
\text { the Estimate }\end{array}$ \\
\hline 1 & $.454^{\mathrm{a}}$ & .206 & .194 & 3.74685 \\
\hline
\end{tabular}

a. Predictors: (Constant), Komunikasi

Sumber : hasil Pengelolahan Data SPSS 24

Berdasarkan tabel 4.20 angka koefisien determinasi yang didapat adalah sebesar 0,206. angka tersebut apabila dikalikan dengan $100 \%$ maka hasil yang didapat adalah sebesar 20,60\%. Artinya, kontribusi yang diberikan Komunikasi terhadap perubahan yang terjadi pada Produktivitas Kerja adalah sebesar 20,60\%, sedangkan sisanya sebesar $79,40 \%$ disebabkan oleh variabel lain yang tidak diteliti.

c. Koefisien Determinasi Variabel Beban Kerja (X1) dan Komunikasi (X2) terhadap Produktivitas Kerja (Y)

Berdasarkan perhitungan SPSS, maka hasil perhitungan dapat dilihat pada tabel 4.21 dibawah ini :

Tabel 4.21

Koefisien Determinasi $\mathbf{X}_{1} \mathbf{X}_{2} \mathbf{Y}$ Model Summary

\begin{tabular}{|c|c|c|c|c|}
\hline \multicolumn{5}{|c|}{ Model Summary } \\
\hline Model & $\mathrm{R}$ & $\begin{array}{c}\mathrm{R} \\
\text { Square }\end{array}$ & $\begin{array}{l}\text { Adjusted R } \\
\text { Square }\end{array}$ & $\begin{array}{l}\text { Std. Error of the } \\
\text { Estimate }\end{array}$ \\
\hline 1 & $.503^{\mathrm{a}}$ & .253 & .230 & 3.66187 \\
\hline
\end{tabular}

a. Predictors: (Constant), Komunikasi, Beban Kerja Sumber : hasil Pengelolahan Data SPSS 24
Berdasarkan tabel 4.21, angka koefisien determinasi yang didapat adalah sebesar 0.253. angka tersebut apabila dikalikan dengan $100 \%$ maka hasil yang didapat adalah sebesar 25,30\%. Artinya, kontribusi yang diberikan Beban Kerja dan Komunikasi terhadap perubahan yang terjadi pada Produktivitas Kerja adalah sebesar $25,30 \%$, sedangkan sisanya sebesar $74,70 \%$ disebabkan oleh variabel lain yang tidak diteliti.

\section{Uji t}

Uji t bertujuan untuk menguji pengaruh signifikan secara parsial yang diberikan oleh Beban Kerja terhadap Produktivitas Kerja. Pengujian menggunakan uji $\mathrm{t}$ dua sisi dengan $\alpha$ sebesar $10 \%$.

\section{a. Uji Hipotesis 1}

Hasil perhitungan nilai t hitung dapat dilihat pada tabel output SPSS dibawah ini :

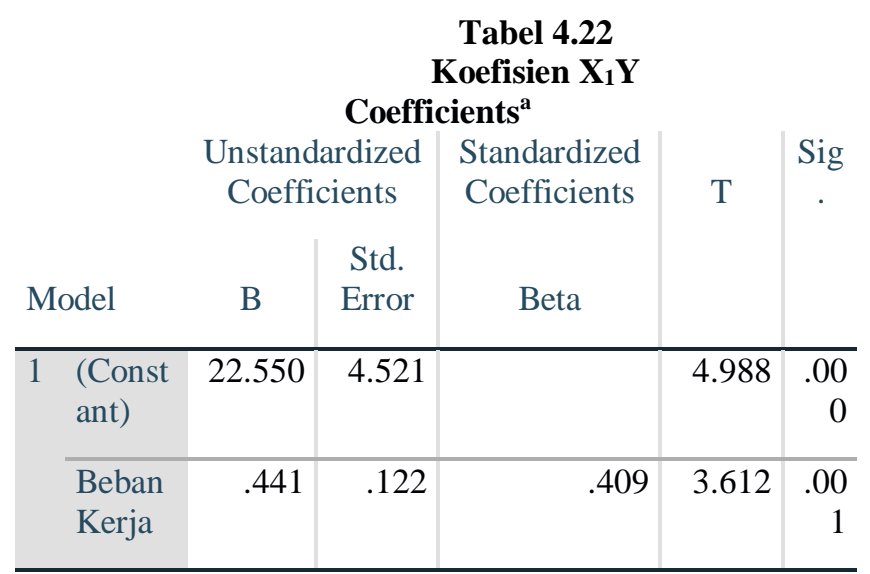

a. Dependent Variable: Produktivitas Kerja

Sumber : hasil Pengelolahan Data SPSS 24

Kriteria uji t dua sisi dilakukan dengan membandingkan nilai $\mathrm{t}$ hitung dengan nilai $\mathrm{t}$ tabel. Berdasarkan tabel 4.22, nilai t hitung yang didapat adalah sebesar 3,612, sedangkan nilai t tabel dengan $\alpha=10 \%$ dan nilai df (derajat bebas $)=\mathrm{n}-\mathrm{k}-1=67-2-1$ 
, dimana $\mathrm{k}$ adalah jumlah seluruh variabel bebas yang diuji. Adalah sebesar 1.669.

Langkah pengujian hipotesis adalah sebagai berikut :

1) Hipotesis dalam bentuk kalimat.

Hipotesis 1: Diduga Beban Kerja berpengaruh terhadap Produktivitas Kerja.

2) Hipotesis dalam bentuk statistik.

Ho : $\rho=0$, tidak terdapat pengaruh.

Ha $: \rho \neq 0$, terdapat pengaruh.

3) Membandingkan nilai t hitung dengan nilai t tabel.

Pengujian dilakukan dengan menggunakan uji 2 sisi dengan cara membandingkan nilai $\mathrm{t}$ hitung dengan nilai t tabel.

4) Membuat keputusan.

Dapat diketahui bahwa $\mathrm{t}$ hitung $>\mathrm{t}$ tabel atau 3,612 > 1.669. Nilai t hitung tersebut berada pada daerah penolakan Ho. Maka hasil pengujian menyatakan Ho ditolak dan Ha diterima.

Artinya, Beban Kerja berpengaruh secara signifikan Produktivitas Kerja di PT. Woneel Midas Leathers.

\section{b. Uji hipotesis 2}

Dari hasil perhitungan nilai $\mathrm{t}$ hitung dapat dilihat pada tabel 4.23 output SPSS dibawah ini :

Tabel 4.23

Koefisien $\mathrm{X}_{2} \mathrm{Y}$ Coefficients $^{\mathrm{a}}$

\begin{tabular}{|c|c|c|c|c|c|}
\hline Model & $\begin{array}{c}\text { Unstanc } \\
\text { Coeff } \\
\text { B }\end{array}$ & $\begin{array}{l}\text { Irdized } \\
\text { ients } \\
\text { Std. } \\
\text { Error } \\
\end{array}$ & $\begin{array}{c}\text { Standardized } \\
\text { Coefficients } \\
\text { Beta }\end{array}$ & $\mathrm{T}$ & Sig. \\
\hline 1 (Constant) & 22.240 & 4.058 & & 5.481 & .000 \\
\hline $\begin{array}{l}\text { Komunika } \\
\text { si }\end{array}$ & .439 & .107 & .454 & 4.105 & .000 \\
\hline
\end{tabular}

a. Dependent Variable: Produktivitas Kerja

Sumber : hasil Pengelolahan Data SPSS 24

Langkah pengujian hipotesis adalah sebagai berikut :

1) Hipotesis dalam bentuk kalimat.

Hipotesis 2 : Diduga Komunikasi berpengaruh terhadap Produktivitas Kerja

2) Hipotesis dalam bentuk statistik.

Ho $: \rho=0$, tidak terdapat pengaruh.

Ha $: \rho \neq 0$, terdapat pengaruh.
3) Membandingkan nilai t hitung dengan nilai t tabel.

Pengujian dilakukan dengan menggunakan uji 2 sisi dengan cara membandingkan nilai t hitung dengan nilai t tabel. Dapat diketahui bahwa $\mathrm{t}$ hitung > t tabel atau 4,105>1.669. Nilai $\mathrm{t}$ hitung tersebut berada pada daerah penolakan Ho. Maka hasil pengujian menyatakan Ho ditolak dan Ha diterima.

Artinya,

Komunikasi

berpengaruh secara signifikan terhadap Produktivitas Kerja di PT. Woneel Midas Leathers.

\section{Uji f (Simultan)}

Uji f bertujuan untuk menguji pengaruh signifikan secara simultan yang diberikan oleh Beban Kerja dan Komunikasi terhadap Produktivitas Kerja. Pengujian menggunakan uji f dengan $\alpha$ sebesar $10 \%$.

Tabel 4.24

\begin{tabular}{|c|c|c|c|c|c|}
\hline \multirow[b]{2}{*}{ Model } & \multicolumn{5}{|c|}{$\begin{array}{l}\text { Koefisien } \mathbf{X}_{1} \mathbf{X}_{2} \mathbf{Y} \\
\text { ANOVA }^{\mathrm{a}}\end{array}$} \\
\hline & $\begin{array}{l}\text { Sum of } \\
\text { Squares }\end{array}$ & $\mathrm{df}$ & $\begin{array}{l}\text { Mean } \\
\text { Square }\end{array}$ & $\mathrm{F}$ & Sig. \\
\hline 1 Regression & 290.880 & 2 & 145.440 & 10.846 & $.000^{\mathrm{b}}$ \\
\hline Residual & 858.194 & 64 & 13.409 & & \\
\hline Total & 1149.075 & 66 & & & \\
\hline
\end{tabular}

a. Dependent Variable: Produktivitas Kerja

b. Predictors: (Constant), Komunikasi, Beban Kerja

Sumber : hasil Pengelolahan Data SPSS 24

Kriteria uji f dilakukan dengan membandingkan nilai f hitung dengan nilai $f$ tabel. Berdasarkan tabel 4.24, nilai f hitung yang didapat adalah sebesar 10.846. Sedangkan nilai $\mathrm{f}$ tabel dengan $\alpha$ sebesar $10 \%$ dapat diperoleh dengan menentukan nilai df N1 (derajat bebas pembilang) yaitu, k $=2$, dimana $\mathrm{k}$ adalah jumlah seluruh variabel bebas yang diteliti. Sedangkan untuk menentukan nilai df $\mathrm{N} 2$ (derajat bebas penyebut) yaitu, $\mathrm{n}-\mathrm{k}-1=67-2-1=64$. Maka, nilai $f$ tabel yang diperoleh adalah 2,39 .

Langkah pengujian hipotesis adalah sebagai berikut.

a. Hipotesis dalam bentuk kalimat.

Hipotesis : Diduga Beban Kerja dan Komunikasi secara simultan (bersama- 
sama) memiliki pengaruh yang signifikan terhadap Produktivitas Kerja di PT. Woneel Midas Leathers.

b. Hipotesis dalam bentuk statistik.

Ho : $\mathrm{f}$ hitung $<\mathrm{f}$ tabel $=0$, tidak terdapat pengaruh.

Ha : f hitung $>\mathrm{f}$ tabel $\neq 0$, terdapat pengaruh.

c. Membandingkan nilai $\mathrm{f}$ hitung dengan nilai $f$ tabel.

Nilai f hitung yang di peroleh adalah sebesar 10.846, sedangkan nilai f tabel diperoleh sebesar 2,39. Maka, dapat diketahui bahwa nilai f hitung $>\mathrm{f}$ tabel $(10.846>2,39)$.

d. Membuat keputusan.

Karena f hitung > dari f tabel, maka hasil pengujian menyatakan Ho ditolak dan Ha diterima. Artinya, Beban Kerja dan Komunikasi secara simultan berpengaruh signifikan terhadap Produktivitas Kerja di PT. Woneel Midas Leathers.

\section{KESIMPULAN DAN SARAN}

\section{A. Kesimpulan}

Terdapat 4 (empat) hipotesis yang diajukan dalam penelitian ini. Dari hasil analisis data dengan menggunakan regresi linier sederhana dan berganda dapat diperoleh kesimpulan sebagai berikut:

1. Pengaruh Beban Kerja terhadap Produktivitas Kerja

Berdasarkan hasil penelitian secara parsial (uji t) diperoleh kesimpulan bahwa variabel beban kerja berpengaruh terhadap produktivitas kerja karyawan pada PT. Woneel Midas Leathers. Dengan nilai uji t memperoleh thitung sebesar $(3,612)>t_{\text {tabel }}(1.669)$. Dengan Taraf Signifikansi $\beta$ sebesar $(0.001)<\alpha$ sebesar $(0.1)$ Ini berarti Ho ditolak dan Ha diterima. Artinya terdapat pengaruh secara signifikan antara beban kerja terhadap produktivitas kerja.

2. Pengaruh Komunikasi terhadap Produktivitas Kerja

Untuk variabel komunikasi diperoleh bahwa komunikasi berpengaruh terhadap produktivitas kerja karyawan pada PT. Woneel Midas Leathers. Dengan nilai uji t memperoleh $t_{\text {hitung }}$ sebesar $(4,105)>t_{\text {tabel }}(1.669)$. Dengan Taraf Signifikansi $\beta$ sebesar $(0.000)<\alpha$ sebesar (0.1). Ini berarti Ho ditolak dan Ha diterima. Artinya komunikasi berpengaruh secara signifikan terhadap produktivitas kerja.

3. Pengaruh Beban Kerja dan Komunikasi terhadap Produktivitas Kerja

Untuk uji hipotesis secara simultan atau bersama-sama (uji f). berdasarkan hasil perhitungan, diperoleh nilai $\mathrm{f}$ hitung dari variabel adalah $f_{\text {hitung }}$ sebesar $(10.846)>f_{\text {tabel }}$ (2,39). Dengan Taraf Signifikansi $\beta$ sebesar $(0.000)<\alpha$ sebesar $(0.1)$. Ini berarti Ho ditolak dan Ha diterima yang berarti dapat dikatakan bahwa kedua variabel yakni beban kerja dan komunikasi bersama-sama berpengaruh secara signifikan terhadap produktivitas kerja.

Berdasarkan hasil analisis yang dilakukan pada penelitian ini, koefisien determinasi berganda menunjukkan nilai sebesar 25,30\%. Artinya pengaruh yang diberikan oleh Beban Kerja dan Komunikasi terhadap perubahan yang terjadi pada Produktivitas Kerja adalah sebesar $25,30 \%$. Sedangkan sisanya sebesar $74,70 \%$, persen dijelaskan oleh error dan variabel lain di luar penelitian ini.

\section{B. Saran}

1. Bagi PT. Woneel Midas Leathers Tangerang.

a. Hasil penelitian membuktikan bahwa Komunikasi lebih berpengaruh terhadap Produktivitas Kerja Karyawan. Disarankan kepada PT. Woneel Midas Leathers untuk lebih memperhatikan komunikasi antar karyawan agar terjalinnya komunikasi yang lebih efektif dan meminimalisir terjadinya miss-communication.

b. Berdasarkan pembahasan variabel Beban Kerja menunjukkan bahwa indikator pernyataan tentang karyawan bekerja melebihi batas waktu dalam menjalankan pekerjaan. Untuk itu pimpinan dapat memberikan batas waktu yang sesuai dengan ketentuan yang telah ditetapkan agar produktivitas bisa tetap stabil.

2. Bagi Penelitian Selanjutnya.

a. Bagi peneliti yang tertarik melakukan penelitian sejenis diharapkan untuk mengobservasi dan mengeksplorasi lebih jauh mengenai permasalahan-permasalahan yang 
terdapat pada objek lain pada umumnya dengan menambahkan variabel lain seperti kompensasi, kepuasan kerja, pelatihan kerja dan motivasi kerja, sehingga peneliti dapat mengetahui faktor-faktor apa saja yang berpengaruh terhadap Produktivitas Kerja, selain itu juga disarankan untuk mencoba menggunakan metode kualitatif dalam mendapatkan data dan informasi yang lebih akurat.

b. Variabel yang digunakan untuk penelitian ini sangat sedikit, yaitu hanya 2 (dua) variabel, oleh sebab itu pada penelitian selanjutnya dapat menambahkan variabel lainnya yang berhubungan dengan Produktivitas Kerja Karyawan. Sehingga dapat memberikan gambaran yang lebih luas mengenai faktor apa saja yang mempengaruhi Produktivitas Kerja selain Beban Kerja dan Komunikasi.

\section{DAFTAR PUSTAKA}

A.A. Anwar rabu Mangkunegara. 2012. Manajemen Sumber Daya Manusia. Bandung; PT. Remaja Rosdakarya

Danang Sunyoto, 2015. Penelitian Sumber Daya Manusia: Jagaraksa Buku Seru.

Elaine B. Johnson, PH.D. 2007. Contextual Teaching and Learning. Bandung:MLC.

Erni Trisnawati, 2013, Pengantar Manajemen: Jakarta Kencana Group.

H. Rachmat. 2014. Manajemen Strategik. Pustaka Seia

Hasibuan, S.P. Malayu. 2015. Manajemen Sumber hDaya Manusia. Edisi Revisi. Jakarta; Bumi Aksara

Hindriari, Reni. 2018. Pengaruh Motivasi Terhadap Produktivitas kerja Karyawan pada PT. Usaha Teknik Indonesia. Jurnal
Madani: Ilmu Pengetahuan, Teknologi, dan Humaniora, Vol. 1 No. 1

Kasmir. 2015. Manajemen Sumber Daya Manusia. Jakarta: Rajawali Pers

Marwansyah. 2014. Manajemen Sumber Daya Manusia, Bandung : ALFABETA.

Noor, Juliansyah. 2015. Metodologi Penelitian. Jakarta: PRENADA GROUP.

Ranupandojo, Heidjrachman. 2013. Manajemen Personalia. Edisi ke-4. Yogyakarta: BPFEYOGYAKARTA

Rimbano, Dheo. 2014. Pengaruh Motivasi dan Pengalaman Kerja Terhadap Produktivitas Karyawan Pada Master Group Cash dan Credit Kota Lubuk Linggau. Jurnal Ekonomi Dan Informasi Akuntansi (Jenius), Vol. 4 No. 1

Sugiyono. 2016. Metode Penelitian. Bandung: Alfabeta

Sutrisno Edi, 2013. Manajmen Sumber Daya Manusia: Jakarta, Kencana Pranada Media Group.

Terry, George R. Dalam Afifudin. 2013. Dasardasar Manajemen, (Terje: G.A Ticoalu). Bandung; CV. Alfabeta

Tjutju Yuniarsih dan Suwatno. 2018. Manajemen Sumber Daya Manusia. Bandung; Alfabeta

Usman Effendi, 2015. Asas Manajemen : Jakarta Raja Grafindo.

Widodo, Suparno, Eko, 2014, Pengembangan Sumber Daya Manusia: Pustaka Belajar, Yogyakarta 